\title{
STREAMFLOW AND NUTRIENT DEPENDENCE OF TEMPERATURE EFFECTS ON DISSOLVED OXYGEN IN LOW- ORDER FOREST STREAMS
}

\author{
April Mason, Y. Jun Xu, Philip Saksa, and Adrienne Viosca \\ School of Renewable Natural Resources \\ Louisiana State University Agricultural Center, Baton Rouge, LA 70803 \\ Johnny M. Grace \\ USDA Forest Service - Southern Research Station \\ 520 Devall Drive, Auburn, AL 36830 \\ John Beebe \\ National Council for Air \& Stream Improvement \\ Western Michigan University (Parkview Campus) \\ 4601 Campus Drive \#A-114, Kalamazoo, MI 49008 \\ Richard Stich \\ Plum Creek Timber Company \\ PO Box 717, Crossett, AR 71635
}

Abstract. Low dissolved oxygen (DO) concentrations in streams can be linked to both natural conditions and human activities. In Louisiana, natural stream conditions such as low flow, high temperature and high organic content, often result in DO levels already below current water quality criteria, making it difficult to develop standards for Best Management Practices (BMPs). Along three low-order streams within a West Gulf Coastal Plain watershed in central Louisiana, streamflow conditions, temperature, organic carbon and $D O$ were measured for one year in order to: (1) investigate spatial and seasonal differences in dissolved oxygen, (2) determine factors influencing the temperature dependence of DO concentrations, and (3) assess consequences of high temperature and organic content on dissolved oxygen levels downstream at higher order streams. Streamflow was measured and monthly water samples were collected at 11 locations. Water samples were analyzed for total and dissolved organic carbon. Stream temperature and dissolved oxygen were measured monthly in-situ at each location. The results show overall oxygen depletion in most of the sampled streams. There was a wide range of monthly DO levels $\left(0.4\right.$ to $\left.9.0 \mathrm{mg} \mathrm{L}^{-1}\right)$ with the lowest levels generally occurring from May to July. On average, DO levels at the sites varied from 2.0 to $6.1 \mathrm{mg} \mathrm{L}^{-1}$. The stream site with the lowest average total organic carbon $\left(7.74 \mathrm{mg} \mathrm{L}^{-1}\right)$ also showed DO meeting TMDL standards $\left(\geq 5 \mathrm{mg} \mathrm{L^{-1 }}\right)$. This site, located near the headwaters of Spring Creek, is impacted the least by organic material transported downstream. There was a close relationship between organic carbon and dissolved oxygen, which appeared to be further affected by stream hydrologic conditions. In the forestdominated landscape of central Louisiana, it may not be possible to reduce nutrient concentrations sufficiently to limit dissolved oxygen consumption, implying that existing water quality standards may not adequately address natural conditions.

Keywords. Dissolved oxygen, TMDL, Dissolved Organic Carbon, Ouachita River Basin, Louisiana

\section{INTRODUCTION}

Low dissolved oxygen in a water body can result from nutrient or organic matter enrichment due to anthropogenic activities. However, low DO conditions can also be caused by natural environmental variables, such as water stagnation and high temperatures. Many of Louisiana's freshwater streams are characterized by low flow with high organic content and high temperatures during the summer season which may cause low dissolved oxygen levels. These ambient levels tend to be below levels regarded safe for organisms by the Louisiana Department of Environmental Quality. The current acceptable Total Maximum Daily Load (TMDL) for dissolved oxygen in Louisiana is $5 \mathrm{mg} \mathrm{L}^{-1}$ (LDEQ, 2001), but a study by Ice and Sugden (2003) found that $81 \%$ of the sites sampled in Northern Louisiana during the summer were below this standard. Most of these streams were classified as having an organic substrate with "slight" or "stagnant" flow, indicating the effect that substrate and stream velocity can have on dissolved oxygen levels.

The TMDL approach has emerged as a widely-adopted strategy to limit pollution from both point and non-point sources. Development of TMDLs for certain pollutant types may enable watershed managers to enforce constraints on the allowable level of activities concerning that pollutant, making the TMDL approach a protection technique for water quality. If the level of activities or the water quality standards in water bodies violate the recommended values from the TMDL recommendation, a load reduction can be 
suggested for the watershed, making the TMDL approach a restoration technique. TMDLs are being widely used when monitoring streams during land use changes and determining the necessary nutrient reduction to maintain or improve stream health. It is, however, important to note that TMDLs are arbitrary indicators of water quality, and they should not be set at levels which are determined unattainable for natural water conditions. Although the current TMDL for dissolved oxygen in Louisiana is $5 \mathrm{mg} \mathrm{L}^{-1}$, some propose a $3 \mathrm{mg}$ $\mathrm{L}^{-1}$ minimum during summer months (LDEQ, 2001). It is argued that the current level is nearly impossible for streams in Louisiana to maintain due to naturally occurring conditions.

Organic carbon has been found to be indirectly related to oxygen availability in water (Thunell et al., 2000), therefore high organic carbon may be an indicator of low dissolved oxygen in natural stream systems. Carbon sources can be locally available within the stream, recycled from upstream transport, or input from runoff or leaf litter (Thomas et al., 2005). Streams sampled in Louisiana tend to have high organic matter, so it can also be responsible for decreased dissolved oxygen levels.

This study is being conducted to assess potential harvesting effects on dissolved oxygen conditions in a forested watershed of central Louisiana. Since the research is in progress, this paper reports preliminary results on (1) spatial and seasonal differences in dissolved oxygen, (2) factors influencing the temperature dependence of dissolved oxygen concentrations, and (3) consequences of higher temperature and organic content on dissolved oxygen in higher order streams.

\section{METHODS}

Study Area

Flat Creek Watershed is located in the western part of the Ouachita River Basin in central Louisiana (Figure 1). The Ouachita River drains a $41,439 \mathrm{~km}^{2}$ basin with topography progressing from slightly rolling uplands to level floodplains. Flat Creek is a medium sized watershed with a drainage area of approximately $350 \mathrm{~km}^{2}$, which comprises about $15 \%$ of the area in Castor Creek Watershed. Land use within the watershed is dominated by forests covering $61 \%$ of the area, followed by rangeland at $21 \%$ (LDEQ, 2001). Four streams in the Flat Creek Watershed were sampled: Spring Creek, Turkey Creek, Big Creek, and Flat Creek.

Louisiana's climate is semi-tropical with hot, humid summers and mild winters. Average temperatures range from $2.3^{\circ} \mathrm{C}-34.1^{\circ} \mathrm{C}\left(36.2^{\circ} \mathrm{F}\right.$ to $\left.93.3^{\circ} \mathrm{F}\right)$, and precipitation averages about $1500 \mathrm{~mm}$ per year.

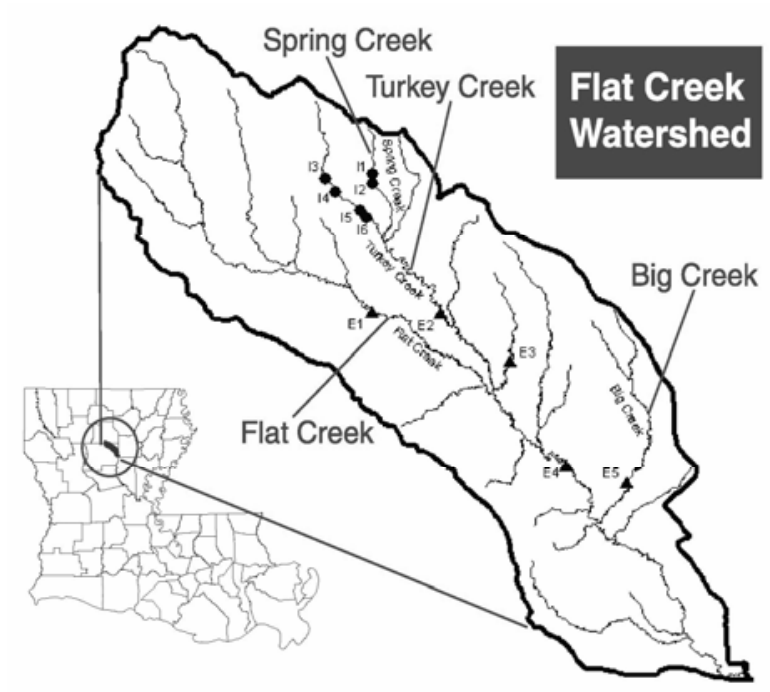

Figure 1. Geographical location of the Flat Creek Watershed and water quality monitoring sites.

In-stream Water Quality Measurements

Eleven sites were visited monthly from January 2006 to November 2006 (Figure 1). In-situ water quality measurements, including dissolved oxygen, temperature, conductivity, and $\mathrm{pH}$ were taken at each site with an YSI 556 multiprobe (Yellow Springs Instruments, Ohio). Streamflow was also recorded at each 
site. In addition, two in-stream water quality monitoring sondes (YSI 6600s) were deployed in Turkey Creek. These sondes measured dissolved oxygen, temperature, conductivity, and turbidity at a 15-min time interval, providing information on daily DO fluctuation over the seasons. Data from these sondes, currently under review, were acquired at periodic intervals between June and November of 2006.

\section{Water Sampling and Laboratory Analysis}

Monthly water samples were collected at the eleven monitoring locations. Water samples were analyzed for total and dissolved organic and inorganic carbon using a Shimadzu Total Organic Carbon Analyzer (TOC-V CSN, Shimadzu Corporation, Kyoto, Japan). Carbon data were acquired between January and July of 2006.

\section{RESULTS}

Seasonal and Spatial Variations in Dissolved Oxygen

From March to October, average dissolved oxygen in the Flat Creek Watershed was below $5 \mathrm{mg} \mathrm{L}^{-1}$ (Figure 2). There was a wide range of DO levels $\left(0.40-9.0 \mathrm{mg} \mathrm{L}^{-1}\right)$ with the lowest DO found during the summer months and the highest DO during the winter months. This distinct, seasonal difference suggests that the high temperature and low flow that normally occur during the summer (Figure 3) causes decreased DO levels in the stream (Figure 2).

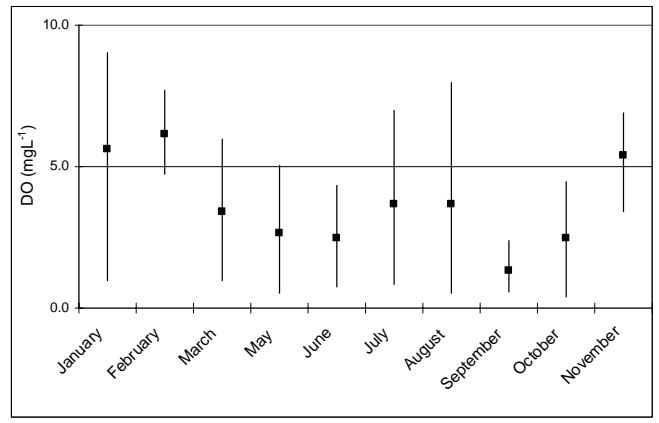

Figure 2: Seasonal dissolved oxygen variability. Square represents the mean of all 11 sites and lines show maximum and minimum value.

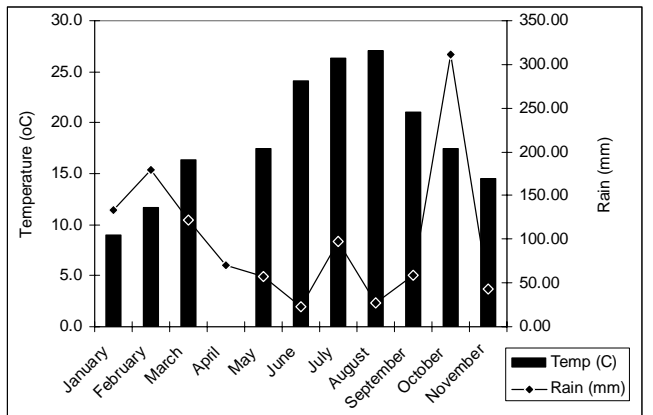

Figure 3. Mean water temperature and monthly rainfall at 11 sites. Temperature data was not available in April.

Intensive monitoring of Turkey Creek showed that a diurnal fluctuation in temperature and DO is present and the lowest DO is found at midday corresponding with the sunniest and warmest part of the day (Figure 4). 


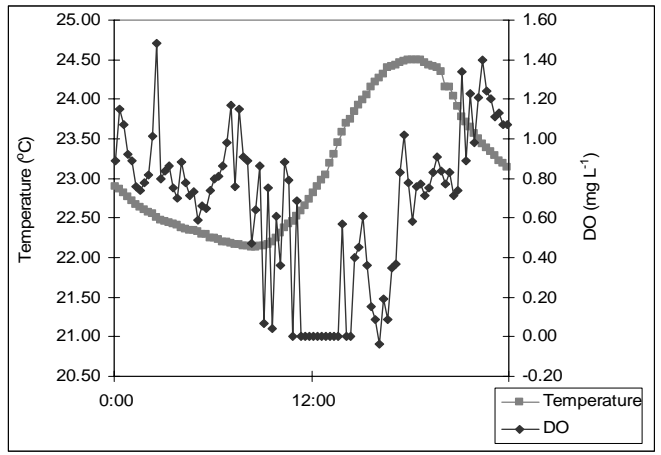

Figure 4. Dissolved oxygen and temperature fluctuation during an early fall day (September 12, 2006) at a site on Turkey Creek.

The variation in dissolved oxygen does not appear to be related to the location of the stream in relationship to the watershed. There is no clear trend in dissolved oxygen and stream order (Table 1). First order streams sampled have average DO between $1.9 \mathrm{mg} \mathrm{L}^{-1}$ to $5.1 \mathrm{mg} \mathrm{L}^{-1}$ and the two $2^{\text {nd }}$ order streams sampled have average DO of $4.3 \mathrm{mg} \mathrm{L}^{-1}$ and $6.0 \mathrm{mg} \mathrm{L}^{-1}$. There is also no clear trend in the change of dissolved oxygen levels from upstream, at the headwaters, to downstream, near the outflow (Figure 5).

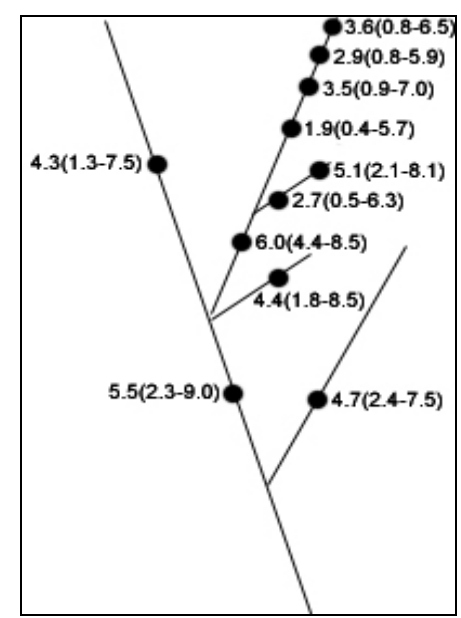

Figure 5. Average dissolved oxygen concentrations (Jan-Nov 2006) along the stream network in the Flat Creek Watershed.

Seasonal and Spatial Variations in Carbon

There were seasonal variations in both average total inorganic carbon (TIC) and total organic carbon (TOC) (Figure 6). TIC increased from $2.22 \mathrm{mg} \mathrm{L}^{-1}$ in January to $12.46 \mathrm{mg} \mathrm{L}^{-1}$ in July. TOC had a peak in the spring months, March and April (22.96 mg L $\mathrm{L}^{-1}$ and $20.45 \mathrm{mg} \mathrm{L}^{-1}$, respectively) and decreased from May to July (17.31 mg L $\mathrm{mg}^{-1}$ to $9.82 \mathrm{mg} \mathrm{L}^{-1}$ ). The inorganic to organic carbon ratio (TIC/TOC) increased from March $\left(0.12 \mathrm{mg} \mathrm{L}^{-1}\right)$ to July $\left(1.27 \mathrm{mg} \mathrm{L}^{-1}\right)$ showing a shift from organic carbon to inorganic carbon as the dominating partition of total carbon. 


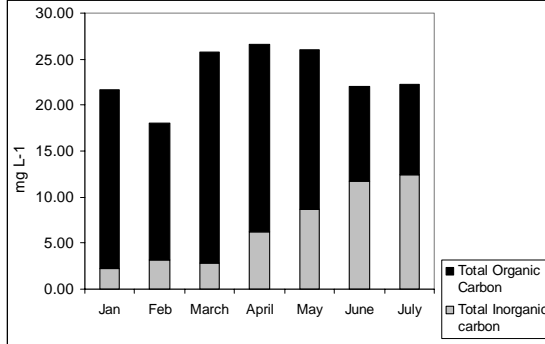

A.

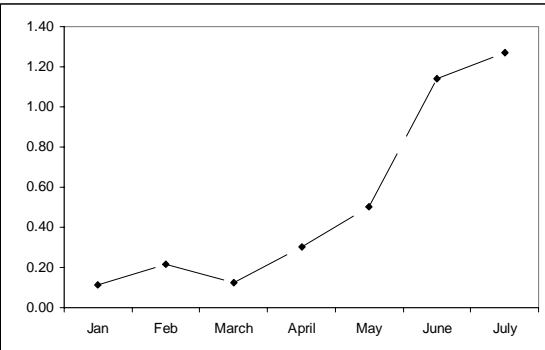

B.

Figure 6. Average monthly carbon values all 11 sites sampled from January, 2006 to July, 2006. A. Organic and inorganic carbon partition of total carbon (whole bar). B. Inorganic carbon to organic carbon ratio for each month.

Dissolved Oxygen and Stream Conditions

The lowest DO levels were found at sites with low velocity (Table 1). Two sites were classified as pools throughout the year. These two sites also experienced low DO with averages of $1.9 \mathrm{mg} \mathrm{L}^{-1}$ and $2.7 \mathrm{mg} \mathrm{L}^{-1}$. The other sites, characterized as non-pools, had higher DO ranging from $2.9 \mathrm{mg} \mathrm{L}^{-1}$ to $6.0 \mathrm{mg} \mathrm{L}^{-1}$.

Table 1. Sites divided based on pools or nonpools with their respective mean DO and discharge.

\begin{tabular}{|c|c|c|c|}
\hline & Order & $\begin{array}{c}\text { Mean DO } \\
\left(\mathrm{mg} \mathrm{L}^{-1}\right)\end{array}$ & $\begin{array}{l}\text { Velocity } \\
\left(\mathrm{cm} \mathrm{s}^{-1}\right)\end{array}$ \\
\hline Pools & & & \\
\hline 16 & $1 \mathrm{st}$ & 1.9 & 0.03 \\
\hline 12 & $1 \mathrm{st}$ & 2.7 & 0.74 \\
\hline \multicolumn{4}{|l|}{ Nonpools } \\
\hline 14 & $1 \mathrm{st}$ & 2.9 & 1.02 \\
\hline 15 & $1 \mathrm{st}$ & 3.5 & 3.13 \\
\hline 13 & $1 \mathrm{st}$ & 3.6 & 1.98 \\
\hline E1 & 2nd & 4.3 & 3.47 \\
\hline E3 & $1 \mathrm{st}$ & 4.4 & 3.24 \\
\hline E5 & $1 \mathrm{st}$ & 4.7 & 4.74 \\
\hline I1 & $1 \mathrm{st}$ & 5.1 & 12.95 \\
\hline E4 & $3 r d$ & 5.5 & 2.53 \\
\hline E2 & 2nd & 6.0 & 19.18 \\
\hline
\end{tabular}

\section{DISCUSSION}

Relationship between Dissolved Oxygen and Environmental Conditions

Naiman (1983) found that as stream order increases, DO also increases as a result of increased primary production. In this study, all streams sampled were relatively low order $\left(1^{\text {st }}-3^{\text {rd }}\right)$ and there was no clear trend of increasing DO with increasing order. In general, these streams have low flow velocities, which is typical of this area. Flow is normally lowest during the summer months, when higher flows could benefit overall oxygen capacity. As a result of this reduced flow and increased temperature, seasonal differences in dissolved oxygen are clearly defined, as found in a similar study by Chapman and Kramer (1991). With Louisiana's extended summers, this seasonal impact on DO can be seen for much of the year.

Localized velocity and morphology influenced dissolved oxygen more than the stream position in the watershed. Local stream morphology has a large effect on DO, as seen in the decreased DO present in 
pools. Distinct characterization of sites as "pool" or "non-pool” is difficult, however. There are a few sites that were classified as non-pools, but are pools during certain low water levels. For example, I4 is a pool during low water conditions, but is not a pool at other water levels. I4 also experienced among the lowest DO levels.

Relationship between Dissolved Oxygen and Dissolved Organic Carbon

Dissolved organic carbon fluxes play a critical role in terrestrial ecosystems. They interact with the biogeochemical nitrogen cycle (Qualls et al., 1991; Campbell et al., 2000), aid in pollutant transport (Kalbitz et al., 2000), and may be a major energy source for microorganisms (Tranvik, 1992). In aquatic environments, organic carbon is either consumed by the biological community, deposited in the benthic zone, or transformed into atmospheric carbon. Land surface processes, climate variation, and anthropogenic activities can all influence organic carbon fluxes. Organic carbon from increased primary production further enhances oxygen consumption (Trefry et al., 1994). In Flat Creek Watershed, we observed increased organic carbon during the spring, probably due to primary production, which began to decrease in early summer.

The decrease in dissolved oxygen to less than $5 \mathrm{mg} \mathrm{L}^{-1}$ began in March, possibly a result of the increasing temperature and organic carbon present in the stream. We also observed a shift in the TIC/TOC ratio from organic carbon dominance in January to inorganic carbon dominance in June (Figure 6). Water levels were observed at their lowest point in the summer season, enhancing the soil-to-water interaction and potentially increasing inorganic carbon found in the water column. Summer 2006 had normal precipitation, which is usually low in this area. With low precipitation, runoff to the stream is also reduced. Runoff may be a source of organic carbon input. Carbon can also be impacted by stream morphology, as pools allow carbon to accumulate which can further decrease DO concentrations.

Applicability of EPA Criteria

This study showed that average DO was below the $5 \mathrm{mg} \mathrm{L}^{-1}$ water quality standard from January 2006 to November 2006 at eight of the eleven sites sampled in Flat Creek Watershed. Average dissolved oxygen levels met state standards for only three out of the eleven months sampled (January, February, November), in which water temperatures were also below $15^{\circ} \mathrm{C}\left(59^{\circ} \mathrm{F}\right)$. These three months are also the period of least vegetation growth in and around the stream channel. Based on our observations it is proposed that a DO concentration of $5 \mathrm{mg} \mathrm{L}^{-1}$ is not achievable even for natural, undisturbed watersheds in Louisiana. The sampled sites, although they are not in pristine or primary forests, have not been fully harvested in nearly 10 years. Aust and Blinn (2004) demonstrated that most harvested sites recover within five years. Considering that the sites are in a rural forested area, these streams are experiencing near natural conditions and are not being heavily influenced by land use changes.

In our study, changes in DO concentrations were most likely affected by seasonality and, therefore the TMDL applied to this area and similar areas in Louisiana should be adjusted accordingly to account for seasonal load allocations for DO. With Louisiana's subtropical climate, the summer extends beyond the traditional three month season. With an impractical water quality standard established in the TMDL, it is difficult to regulate land use changes, as well as to determine if BMPs are working effectively.

\section{CONCLUSION}

Dissolved oxygen is impacted largely by seasonality and temperature. There is also a seasonal relationship in the inorganic carbon to organic carbon ratio. Localized environmental conditions such as stream velocity and morphology are more indicative of dissolved oxygen levels than stream order. With natural dissolved oxygen concentration in Louisiana streams below the TMDL recommendation of $5 \mathrm{mg} \mathrm{L}^{-1}$, it may not be possible to reduce nutrient concentrations sufficiently to limit dissolved oxygen consumption, implying that currently established water quality standards do not adequately address natural conditions.

\section{ACKNOWLEDGEMENTS}

We thank Louisiana Department of Environmental Quality, USDA Forest Service Southern Research Station, and National Council for Air \& Stream Improvement for their financial support. We especially thank Plum Creek Timber Company for providing the research site and field assistance. 


\section{REFERENCES}

Aust W. M. and C. R. Blinn. 2004. Forestry best management practices for timber harvesting and site preparation in the eastern United States: an overview of water quality and productivity research during the past 20 years. Water, Air, and Soil Pollution 4:5-36.

Campbell J. L., J. W. Hornbeck , W. H. McDowell, D. C. Buso, J. B. Shanley, and G. E. Likens. 2000. Dissolved organic nitrogen budgets for upland, forested ecosystems in New England. Biogeochemistry 49:123-42.

Chapman, L. J., and D. L. Kramer. 1994. Limnological observations of an intermittent tropical dry forest stream. Hydrobiologia 226: 153-166.

Ice, G. and B. Sugden. 2003. Summer dissolved oxygen concentrations in forested streams of Northern Louisiana. Southern Journal of Applied Forestry 27(2):92-99.

Kalbitz K., S. Solinger, J. H. Park, B. Michalzik, and E. Matzner . 2000. Controls on the dynamics of 20 dissolved organic matter in soils: a review. Soil Science 164:(4)277-304.

LDEQ. 2001 Flat Creek Watershed TMDL for oxygen demand. Louisiana Department of Environmental Quality, Office of Environmental Assessment, Environmental Technology Division. Baton Rouge, Louisiana.

Naiman, R.J. 1983. The annual pattern and spatial-distribution of aquatic oxygen-metabolism in Boreal forest watersheds. Ecological Monographs 53:73-94.

Qualls, R. G., B. L. Haines, and W. T. Swank. 1991. Fluxes of dissolved organic nutrients and humic substances in a deciduous forest. Ecology 72(1):254-66.

Thomas, S.A., T. V. Royer, E.B. Snyder, and J. C. Davis. 2005. Organic carbon spiraling in an Idaho river. Aquatic Sciences 67(4): 424-33.

Thunell, R.C., R. Varela, M. Llano, J. Collister, F. Muller-Karger,, and R. Bohrer. 2000. Organic carbon fluxes, degradation, and accumulation in an anoxic basin: Sediment trap results from the Cariaco Basin. American Society of Limnology and Oceanography 45:300-308

Tranvik L. R. 1992. Allochtonous dissolved organic matter as an energy source for pelagic bacteria and the concept of the microbial loop. Hydrobiologia 229:107-14.

Trefry, J.H., S. Metz, T. A. Nelsen, R. P. Trocine, and B. J. Eadie. 1994. Transport of particulate organic carbon by the Mississippi River and its fate in the Gulf of Mexico. Estuaries 17:839-849. 